\title{
Archaeological Survey and Testing at The City of Live Oak Park, Bexar County, Texas
}

\section{Erwin Roemer Jr.}

Stephen L. Black

Department of Anthropology, Texas State University

Follow this and additional works at: https://scholarworks.sfasu.edu/ita

Part of the American Material Culture Commons, Archaeological Anthropology Commons, Environmental Studies Commons, Other American Studies Commons, Other Arts and Humanities Commons, Other History of Art, Architecture, and Archaeology Commons, and the United States History Commons

Tell us how this article helped you.

This Article is brought to you for free and open access by the Center for Regional Heritage Research at SFA ScholarWorks. It has been accepted for inclusion in Index of Texas Archaeology: Open Access Gray Literature from the Lone Star State by an authorized editor of SFA ScholarWorks. For more information, please contact cdsscholarworks@sfasu.edu. 


\section{Archaeological Survey and Testing at The City of Live Oak Park, Bexar County,}

Texas

\section{Creative Commons License}

\section{(c) (1) (9)}

This work is licensed under a Creative Commons Attribution-NonCommercial 4.0 International License 


\title{
ARCHAEOLOGICAL SURVEY AND TESTING AT The City of Live Oak Park, BEXAR COUNTY, TEXAS
}

\author{
ERWIN ROEMER, JR. AND STEPHEN L. BLACK
}

CENTER FOR ARCHAEOLOGICAL RESEARCH THE UNIVERSITY OF TEXAS AT SAN ANTONIO ARCHAEOLOGICAL SURVEY REPORT, NO. 47

1977

UTSA - Center for

Anchacological Researm 


\section{ARCHAEOLOGICAL SURVEY AND TESTING AT \\ THE CITY OF LIVE OAK PARK, BEXAR COUNTY, TEXAS}

Erwin Roemer, Jr. and Stephen L. Black

Center for Archaeological Research The University of Texas at San Antonio Archaeological Survey Report, No. 47 
TABLE OF CONTENTS

Page

Introduction ................... 1

The Survey . . . . . . . . . . . . . . 1

The Excavations ................ 1

Test Unit \#1 ................ 5

Test Unit \#2 ............... 5

Summary and Recommendations .......... 8

References Cited ............. 10

\section{LIST OF FIGURES}

Figure

Page

1. 41 BX 435 Site Plan ............ 2

2. 41 BX 435 Surface Artifacts .......... 3

3. 41 BX 435 Surface Artifacts ........... 4

4. 41 BX 435 Lithic Artifacts from Excavation Units . . 6

5. 41 BX 435: Test Unit \#2 Excavations ........ 9

\section{LIST OF TABLES}

Table

Page

1. Archaeological Materials From Test Units at Si te 41 BX $435 \ldots . . . . . . . .77$ 


\section{INTRODUCTION}

On June 15, 1977, an archaeological survey was made of a 70-acre park at Live Oak, Texas. During the survey, a prehistoric site (4T BX 435) was found and recorded. Recommendations were made for testing the site to evaluate its importance and possible eligibility for nomination to the National Register of Historic Places. On June 17 and 18, 1imited testing of the site was conducted. The results of the survey and subsequent test excavations are presented here.

The archaeological work at the park was done under a contract between the City of Live Oak (Mr. Ronald Dunlap, City Manager) and the Center for Archaeological Research, The University of Texas at San Antonio.

The original survey was conducted by Stephen L. BTack, and the subsequent testing was done by Erwin Roemer, Jr., Augustine Frkuska and Elizabeth Frkuska. Field work was done under the supervision of Dr. Thomas R. Hester, Director of the Center, and Jack D. Eaton, Assistant Director.

\section{THE SURVEY}

At the time of the survey on June 15, 1977, the Live 0ak park was being deve1oped and much of the area had already been modified by heavy equipment. A light scatter of cultural debris, mostly lithic materials, was seen in disturbed fill and grader cuts over much of the park area. Cores, unifaces, bifaces, patinated flakes and burned rocks were observed. It is likely that one or more sites were present in the zone before development began.

On the north side of the development zone, a relatively undisturbed prehistoric site (41 BX 435) was discovered (Fig. 1). The site is located on the south bank of a sma11, dry creek which enters the park site from the northwest. The total size of the site could not be determined, but it appeared to extend along the bank for roughly $75 \mathrm{~m}$ and was perhaps $10 \mathrm{~m}$ wide.

Cultural debris was observed in situ in the profile along the edge of the drainage cut. Eroding from the creek bank were chert flakes, bifaces, burned rocks, bone fragments and land snail she11s. Also noted in the cut was a Montell dart point. A selection of lithic artifacts collected from the surface is shown in Figs. 2 and 3 .

Because the site was in danger of being disturbed by ongoing construction, it was recommended that testing be done, first of a11, to determine the importance of the site and, then, to suggest means to protect it.

\section{THE EXCAVATIONS}

Limited testing was done at site 41 BK 435 in an effort to learn something about its size, depth, content, chronological affiliations and archaeological potential. Standard excavation techniques were used and all soil was screened through a 1/4-inch hardware cloth. 


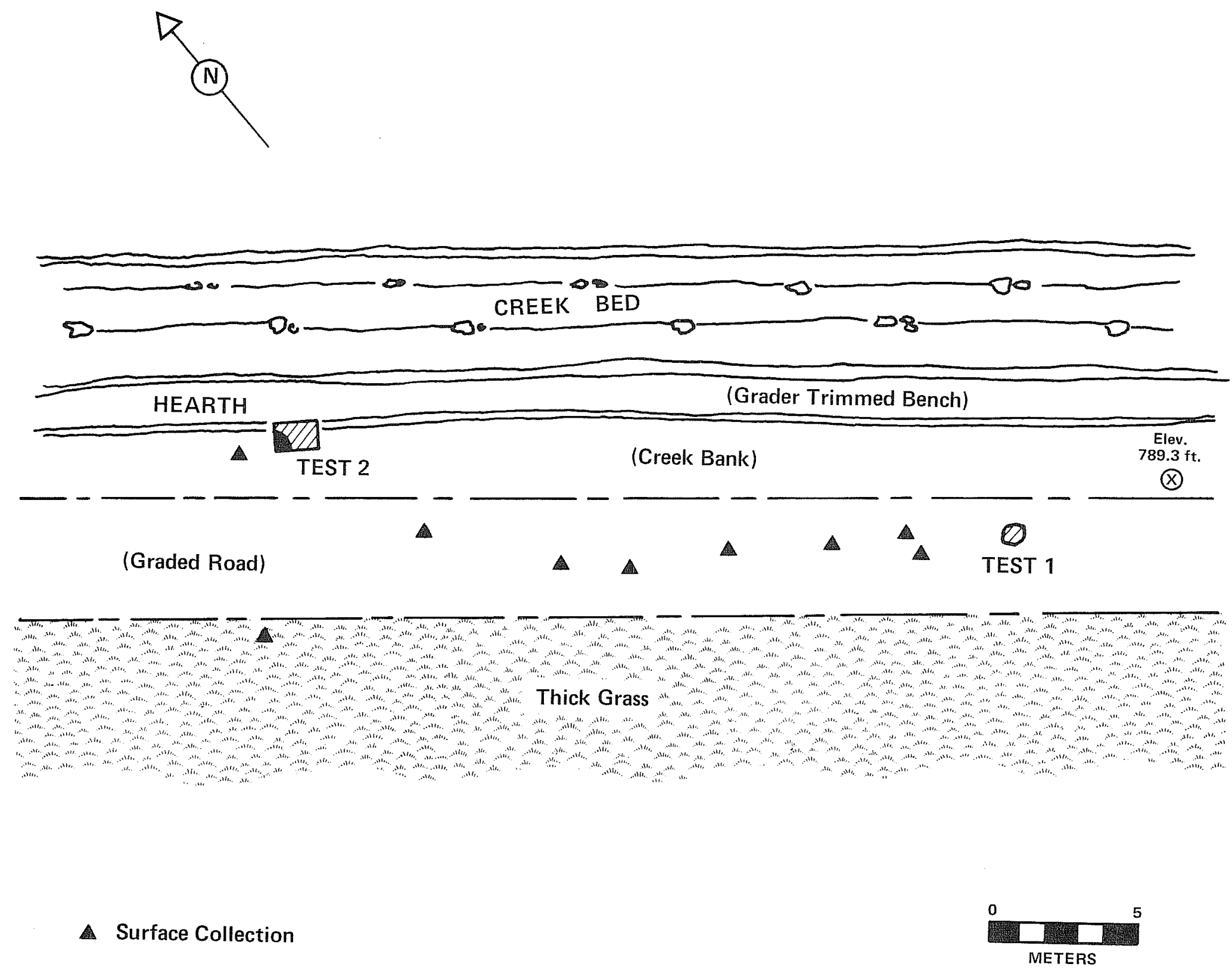

Figure 1. 41 BX 435 Site Plan. Shown are locations of Test Units $\# 1$ and \#2 and surface collection proveniences. 


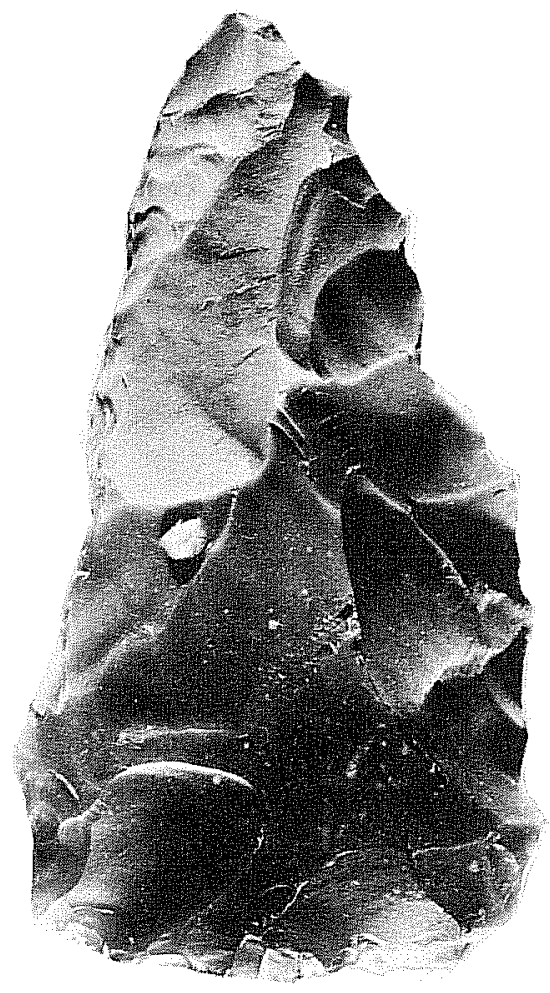

a

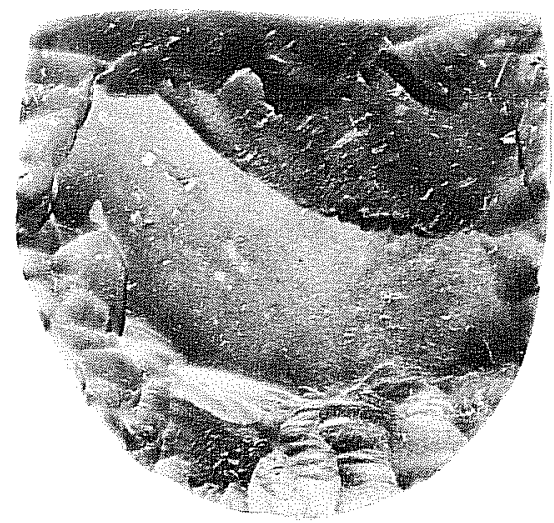

C

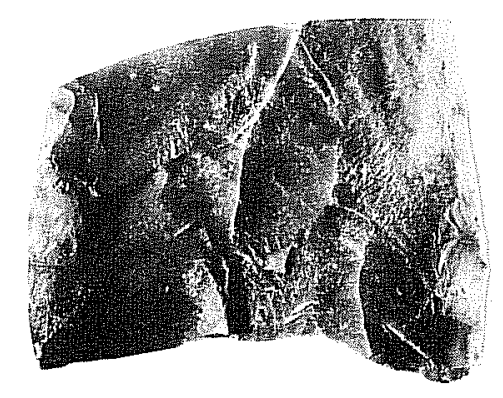

d

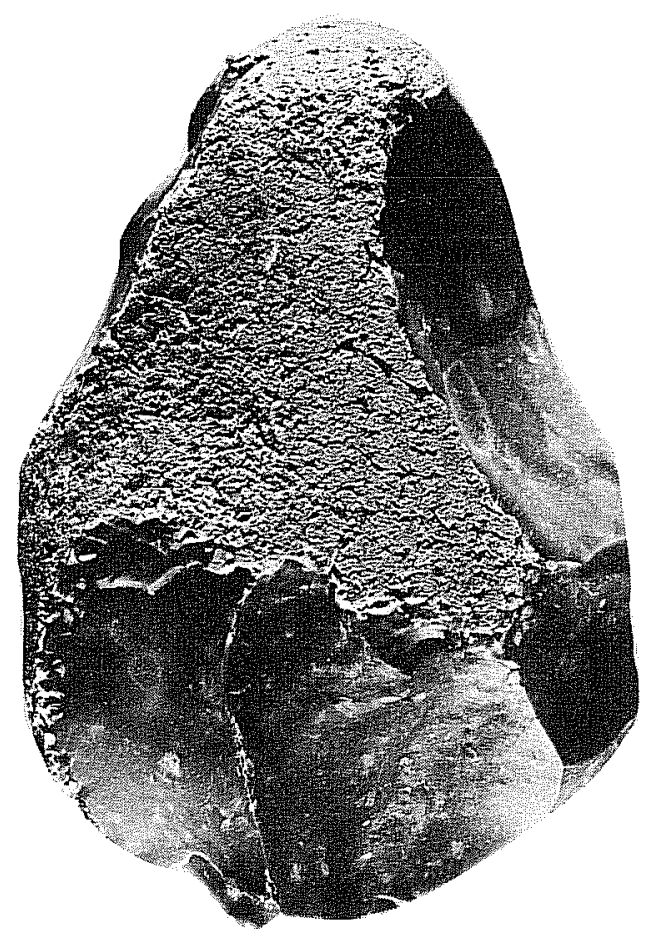

b

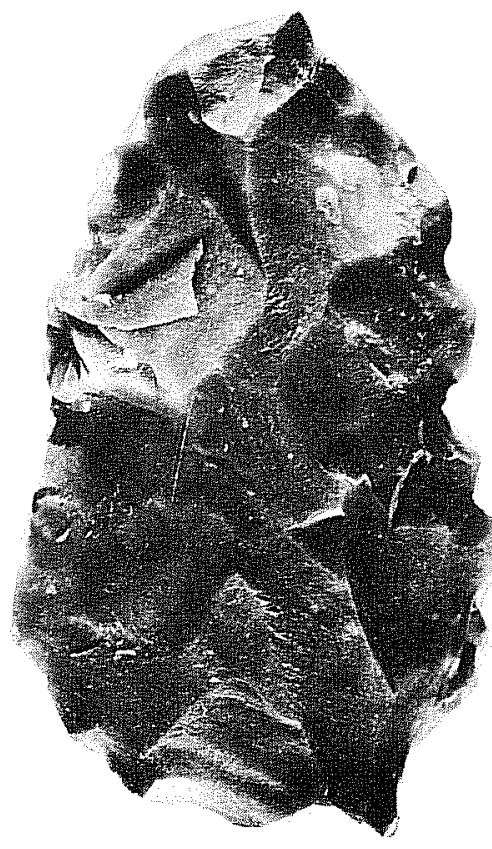

e

\section{$\left.\left.\left.\left.\left.\left.\mathrm{cm}\right|^{\prime}\right|_{1} ^{\prime}\right|_{2}\right|^{\prime} 3\right|^{\prime} 4\right|^{\prime} 5 \mid$}

Figure 2. 41 BX 435 Surface Artifacts. a, bifacial quarry blank; b, bifacial core; c-d, bifacial preform fragment; e, bifacial quarry blank. 


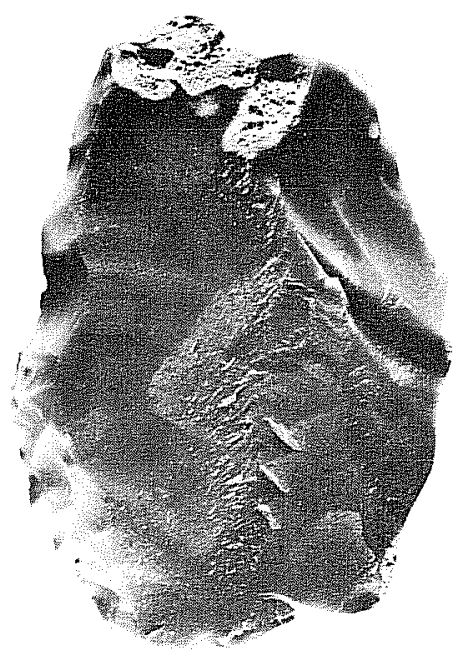

a

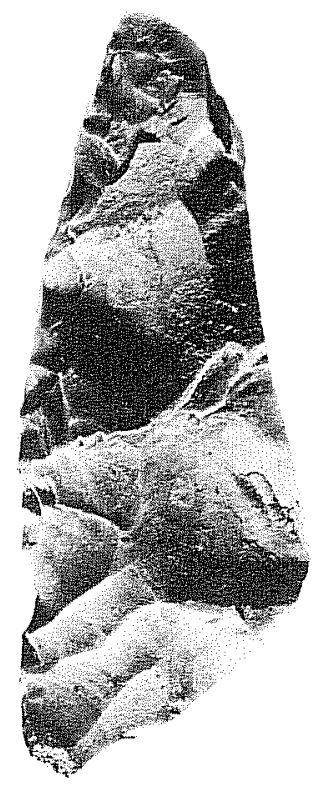

b

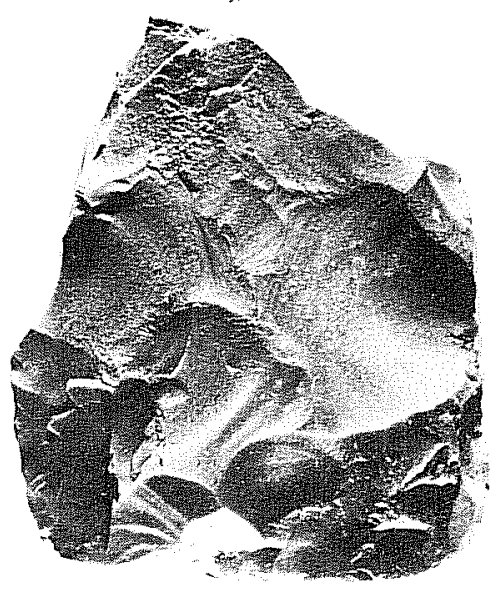

C
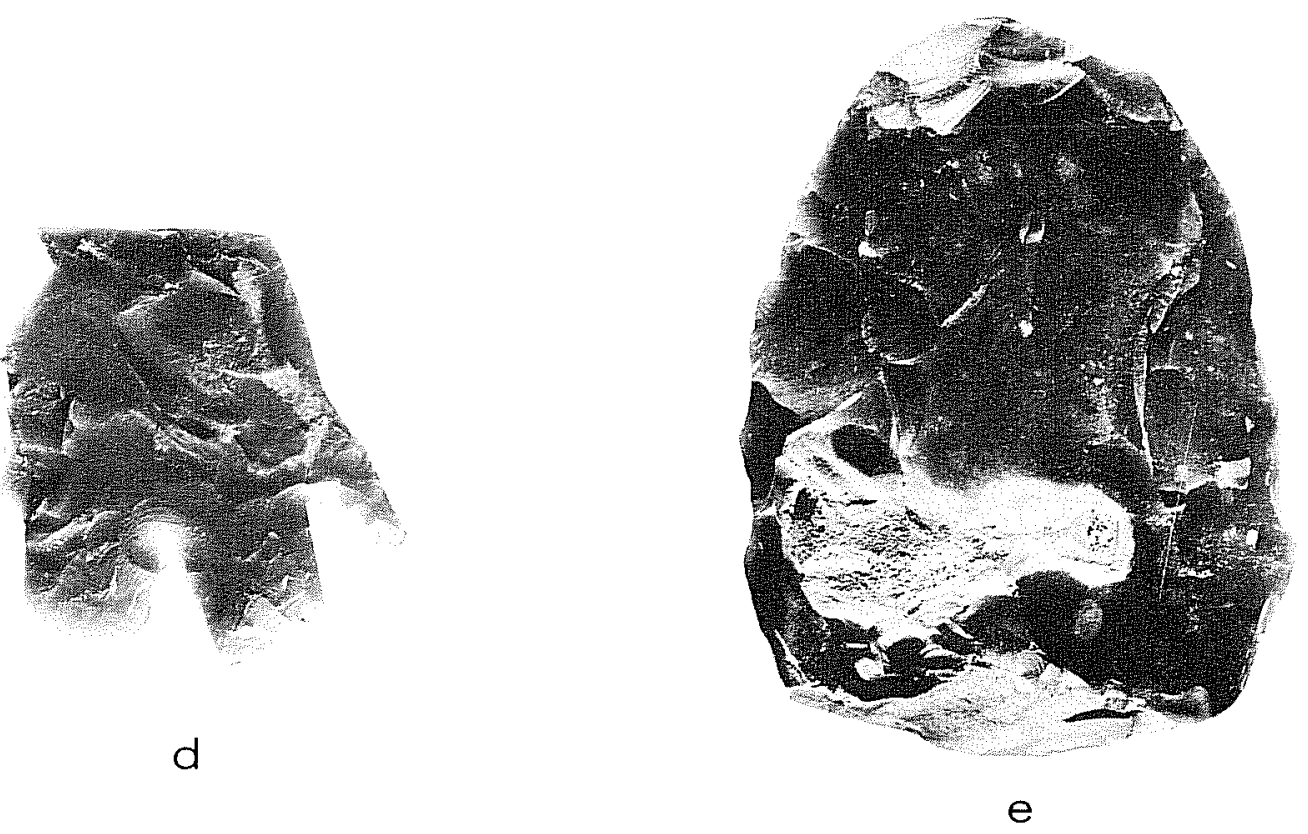

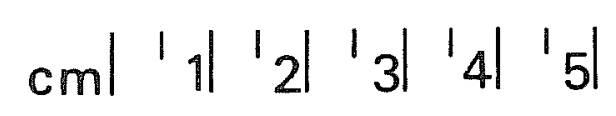

Figure 3. 41 BX 435 Surface Artifacts. a, bifacial preform; b, unifacial side scraper; c, unifacial quarry blank; d, Montell point fragment; e, bifacial quarry blank. 
Investigations at $41 \mathrm{BX} 435$ began with a controlled surface collection of the site. This was followed by the excavation of two test pits (Test Units \#1 and \#2) dug into selected areas of the site (Fig. 1). The artifacts and other cultural debris collected during the excavations are summarized in Table 1.

Test Unit \#1

This was a $40 \mathrm{~cm}^{2}$ pit dug in 10-cm arbitrary leve1s to a depth of $80 \mathrm{~cm}$. The unit was placed in a graded road surface on top of the creek bank about $5 \mathrm{~m}$ from the creek bottom (Fig. 1). It is estimated that several $\mathrm{cm}$ of original surface had been removed by the grader, but the deposits were otherwise undisturbed.

Level 1 (surface to $10 \mathrm{~cm}$ ) contained the largest sample of cultural debris within the unit. The lithics include a unifacial side and end scraper (Fig. 4,a), a core and flakes. Lithic artifacts (mostly flakes) were recorded from every subsequent level except Level 5. Only a few fragments of possibly burned rocks were noted in this level.

The deposits were composed basically of medium brown clayey soil with occasional small inclusions of caliche throughout. The soil was darkest in color in the first two excavation levels $(0-20 \mathrm{~cm})$. This soil continued through the third and fourth levels $(20-40 \mathrm{~cm})$ but with an admixture of light brown clay.

Leve $5(40-50 \mathrm{~cm})$ was notably grayer, loosely packed and contained some sand. This level had no artifacts and, with the exception of two fire-fractured rocks, appeared to be culturally sterile. Extending below this level, to the $80-\mathrm{cm}$ depth at which excavations terminated, was a uniform medium brown clayey soil similar to the upper levels. Artifactual materials (flakes, charcoal, land snails) were present in this deposit (see Table 1).

Although some scattered burned rocks were noted in most levels, no concentrations which might represent a cultural feature were uncovered.

Test Unit \#2

This unit was a $50-\mathrm{cm} \times$ one-m test pit dug into the creek bank. It was placed between the creek bed and the graded road mentioned above. The unit was located about 25 m upstream from Unit \#1.

Unit \#2 was excavated in $10-\mathrm{cm}$ levels to a depth of $90 \mathrm{~cm}$. Lithic artifacts, mostly flakes, were found in quantity in all levels. Also noted in most leve1s were burned rocks, fragments of charcoal and land snail shells. Found in Level 3, at a depth of $28 \mathrm{~cm}$, was an Ensor point (Fig. 4,b). In Level 5 a core fragment with a concave utilized edge was found ( $F i g .4, C$ ), as well as a bovid tooth fragment (probably bison). In Level 6 a bifacial core (Fig. 4,d) and a biface fragment were found.

It is interesting to note that the count of chert flakes and chunks steadily increased with depth, with the largest concentration found in Level 7 . Most of the chunks of chert are fire-burned. Within this level, in the western half of the excavation unit and at the $63-$ to $70-\mathrm{cm}$ depth, a concentration of burned 

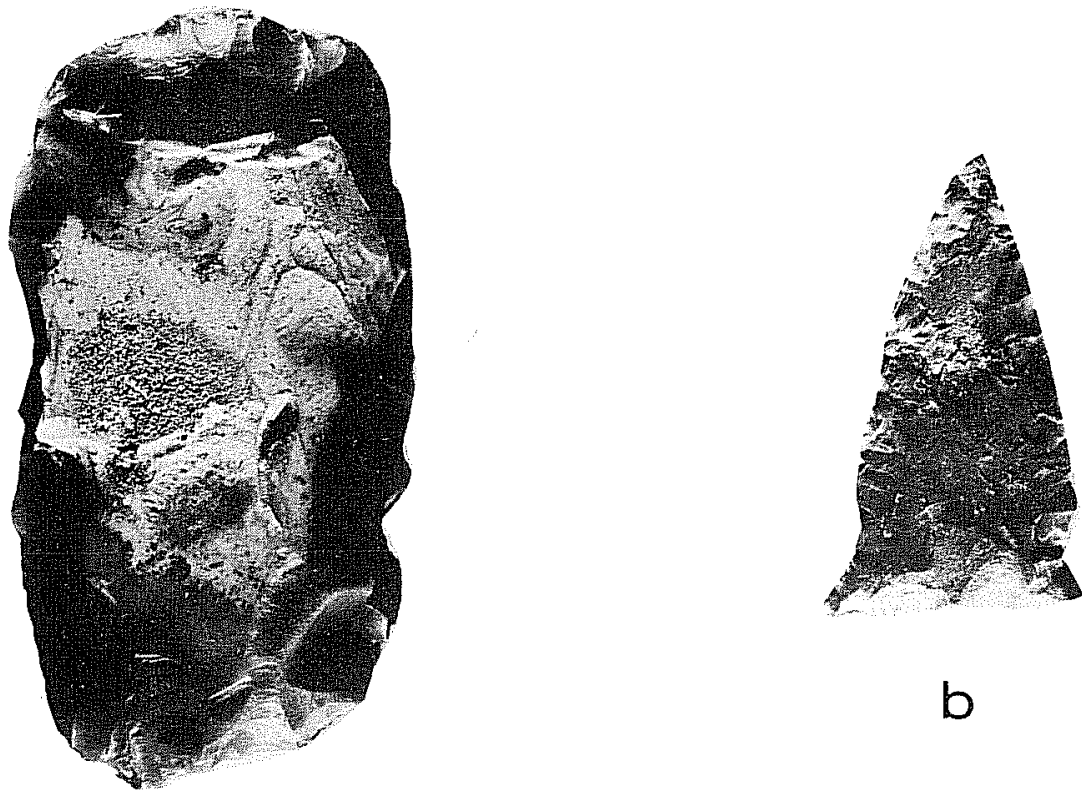

b

a
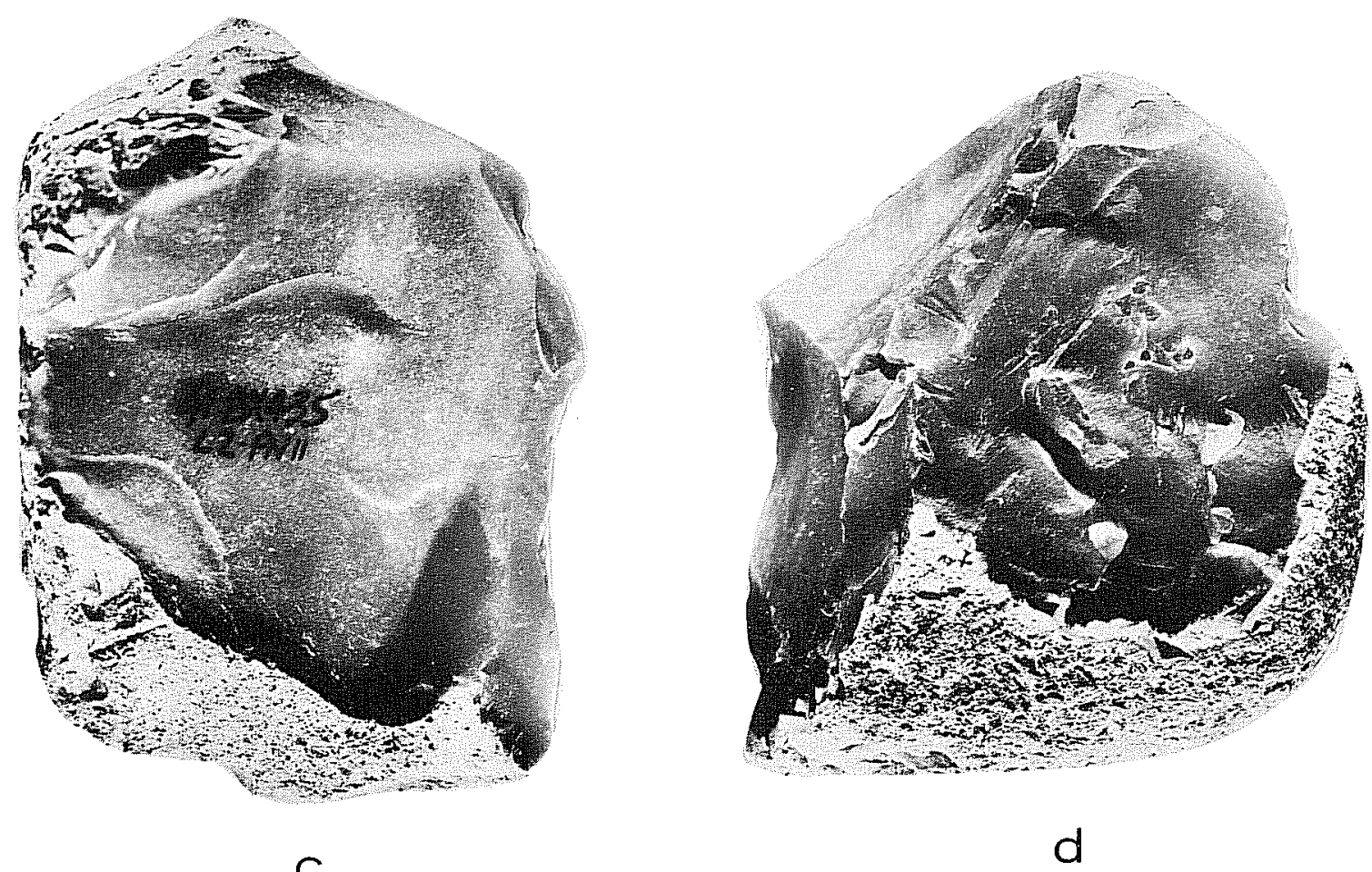

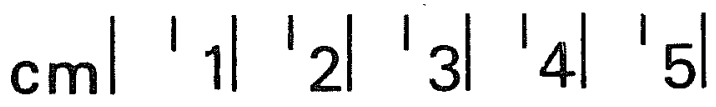

Figure 4. 41 BX 435 Lithic Artifacts from Excavation Units. Unit \#1: a, unifacial side and end scraper; Unit \#2: b, Ensor point; $c$, core fragment; $d$, bifacial core. 
TABLE 1

ARCHAEOLOGICAL MATERIALS FROM TEST UNITS AT SITE 41 BX 435

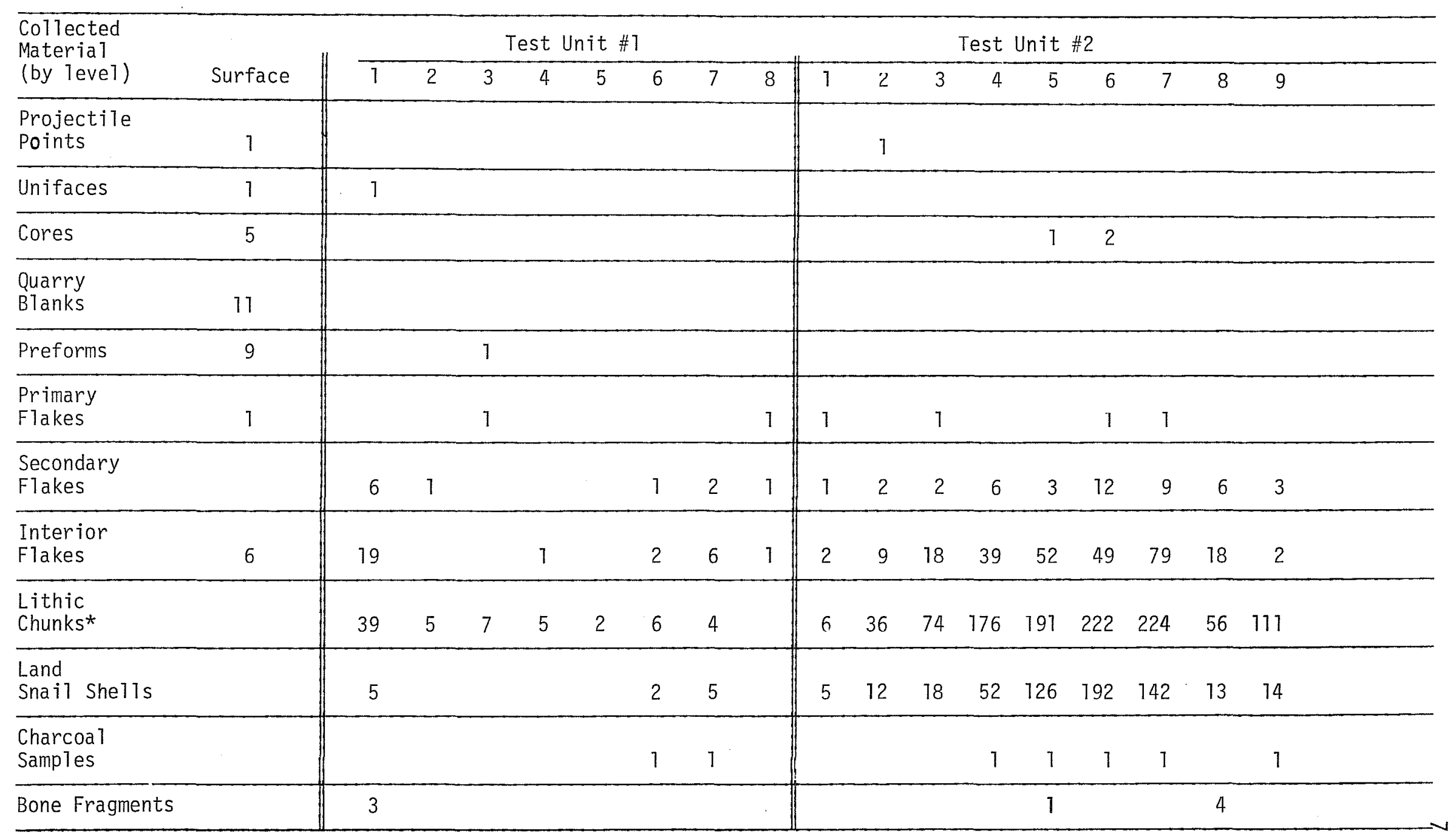

*These were mainly of low-grade chert, fire fractured, and ranged from $.5 \mathrm{~cm}$ to $5 \mathrm{~cm}$ in size. They appear to have been hearth stones. 
rocks (with scattered charcoal in association) was recorded (Fig. 5). This buried burned rock feature had a relatively lighter incidence of flakes within and around it. Near the concentration of burned rocks was a large number of land snail shells (Rabdotus sp.). A hackberry seed was also coliected.

Through Levels 8 and 9 there was a noticeable decline in overall quantities of materials, although the burned rock feature continued as deep as excavations were made. In Level 8 some unidentifiable bone fragments were found.

The soil in Test Unit \#2 was consistently a very hard brown clay with occasional caliche flecks and small gravels. There was some indication of root activity extending to a depth of around $70 \mathrm{~cm}$.

\section{SUMMARY AND RECOMMENDATIONS}

Site 41 BX 435 is a relatively large $\left(750+\mathrm{m}^{2}\right)$ prehistoric occupation site. Parts of the site appear to have been utilized intermittently (e.g., the two "horizons" evident in the vertical distribution of artifacts from Test Unit \#1), while other site areas saw repeated occupations by local hunter-gatherer populations (e.g., the Test Unit \#2 area). Chronologically, the site apparently dates from Late Archaic times, as evidenced by the recovery of Montell and Ensor dart points. Dating of the Late Archaic is uncertain, in terms of absolute temporal parameters, but radiocarbon evidence from south central Texas (at La Jita, Hester 1971; and at Walker Ranch, Jaquier et al. 1977) suggest that it ended about A.D. 800-1000. This is considerably later than the upper time 7 imits suggested for the period by either Prewitt (1976) or Weir (1976) for the centra1 Texas area proper.

The depth of buried deposits, the occurrence of a deeply buried (and as yet unexplored) burned rock accumulation, the presence of considerable 7ithic remains, charcoal and snails, and the potential of these extensive archaeological materials for future scientific studies are all indicative of the significance of this site. Accordingly, we have submitted the appropriate forms for its nomination to the National Register of Historic Places.

As a result of our investigations, the City of Live Dak (as represented by City Manager Ronald E. Dunlap) agreed to protect this site during the completion of work on the park. It is planned, as part of the park development scheme, to cover the entire site surface with a layer of sod. This measure should protect the site both from erosion and from indiscriminate relic collecting. We further suggest that proper management of this important resource should include fencing of the site area. Unless the remaining portions of 41 BX 435 are preserved, south central Texas will lose yet another valuable cultural resource. 


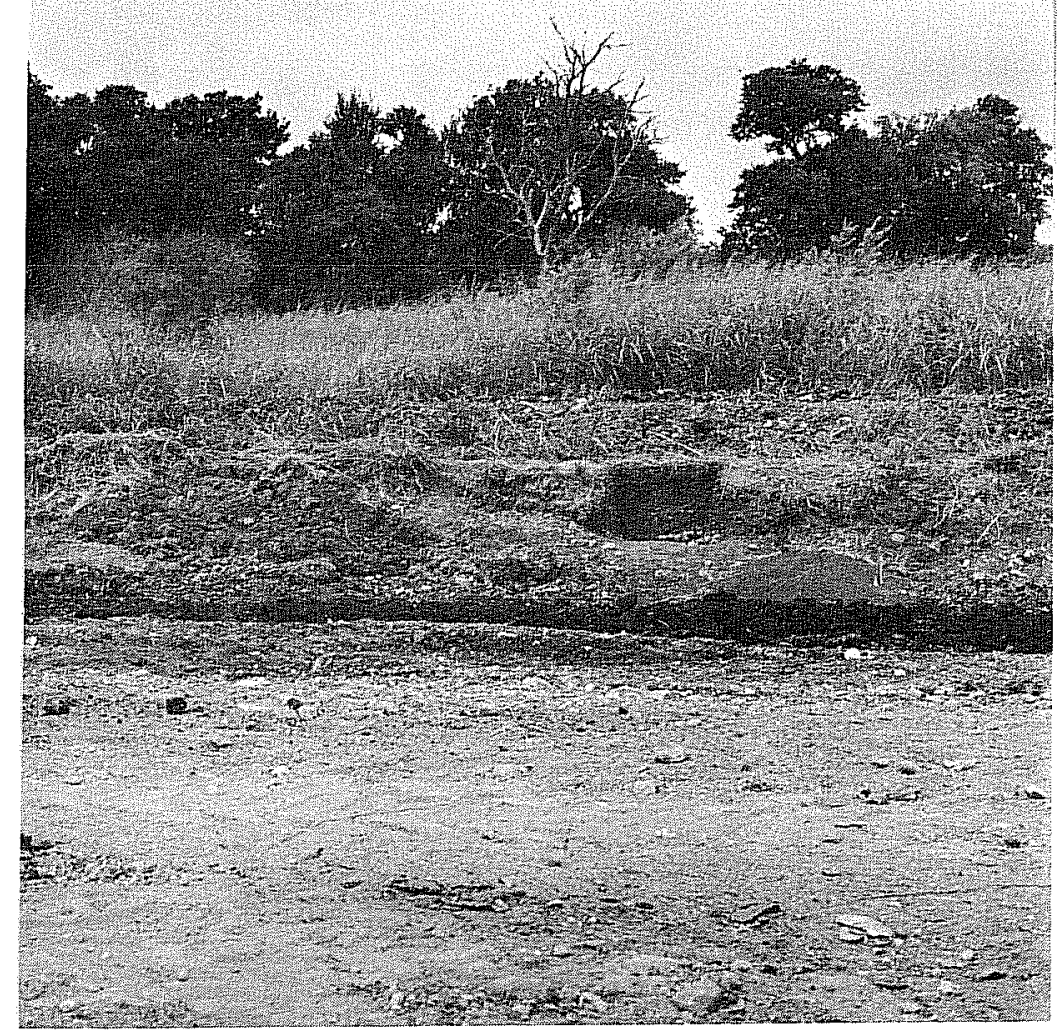

a

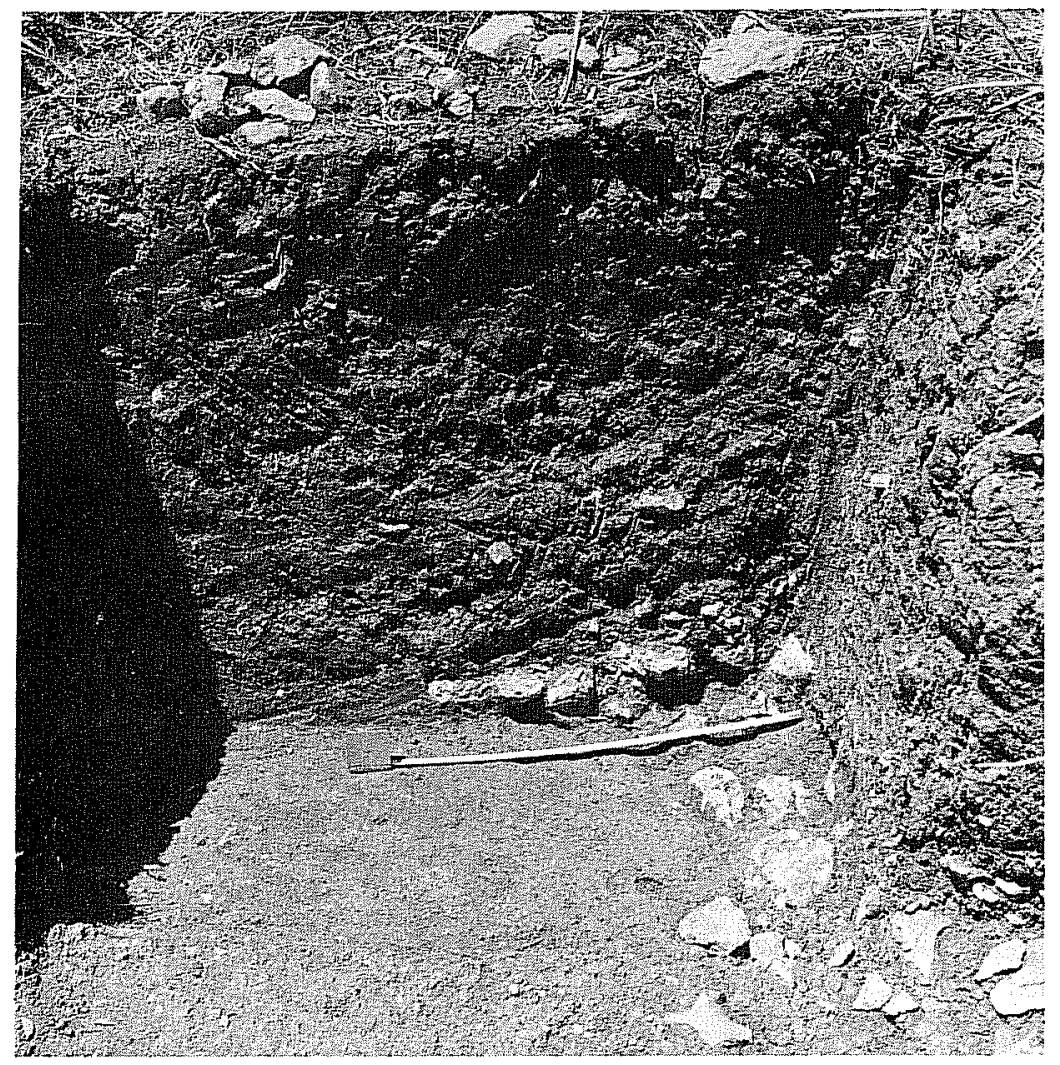

b

Figure 5. 41 BX 435: Test Unit \#2 Excavations. a, view of Test Unit \#2; $b$, Test Unit \#2 south profile; note buried burned rock feature. 


\section{REFERENCES CITED}

Hester, T. R.

1971 Archeological Investigations at the LaJita Site, Uvalde County, Texas. Bulletin of the Texas Archeological Society 42:51-148.

Jaquier, J. A., Waynne Cox and Fred Valdez, Jr.

1977 Test Excavations at Site 41 BX 228 (Walker Ranch), Bexar County, Texas. The University of Texas at San Antonio, Center for Archaeological Research, Archaeological Survey Report 46.

Prewitt, E. R.

1976 Late Archaic Occupations at the Loeve-Fox Site: The San Marcos and Twin Sisters Phases. In: Hester, T. R., ed., The Texas Archaic: A Symposium. The University of Texas at San Antonio, Center for Archaeological Research, Special Report 2:67-82.

Weir, F. A.

1976 The Central Texas Archaic Reconsidered. In: Hester, T. R., ed., The Texas Archaic: A Symposium. The University of Texas at San Antonio, Center for Archaeological Research, Special Report 2: 60-66. 